DOI 10.32900/2312-8402-2020-123-49-58

УДК 636.4.082

\title{
PHENOTYPIC CONSOLIDATION COEFFICIENTS OF BIRTH-WEIGHT INDICATORS IN SOWS OF WELSH BREED
}

\author{
Tsereniuk O. M., dr. agr. sci., assoc. prof., \\ Martyniuk I. M., Ph.D., sen. research., \\ Akimov O. V., Ph.D., sen. research., \\ Shkavro N. M., Ph.D., sen. research., \\ Institute of Animal Science of NAAS
}

Babicz M. dr hab., University of Life Sciences in Lublin, Polska

The aim of the research was to study the effect of sow and boar age on average weight of newly born piglets, considering the season of the year and the age of the animals. The studies were conducted in the research farm of SE "Gontarivka", Volchansky district, Kharkiv region. Natural breeding of sows is used for reproduction on the farm. The insemination of sows was carried out according to the scheme of studies. 35 head of sows and 4 boars of different ages and live weights were selected. Four groups of sows were formed. In order to study the impact of the season of the year on sow productivity, the first series of studies were conducted in the autumn, the second series - in the spring according to the same scheme.

In different groups of animals, average weight of newly born piglets ranged from 1.10 to $1.21 \mathrm{~kg}$. The average value of this indicator for all sows for both studied seasons was $1.16 \mathrm{~kg}$. The magnitude (for all sows of the period) in winter farrowing was $1.74 \%$ higher than the summer farrowing (for all sows of the period), although the difference between these groups was not probable. Between the sows of different ages, inseminated by boars of different ages, in winter, the higher values were given to young sows that were inseminated by young boars ( $p<0.01$ compared to young sows that were inseminated by full-grown boars). Among the sows of different ages, inseminated by boars of different ages, in the summer, the highest values were middle-aged, which were inseminated by middle-aged boars ( $p<0.01$ compared to young sows in winter, inseminated by full boars and $p<0.05$ compared to young sows in summer, which were inseminated by adult boars). During the summer period the middle-aged sows, which were inseminated by middle-aged boars, received maximum values of average weight of newly born piglets, which were higher than sows of other groups by 10.00-0.83\%.

The most consolidated high-birth-weight rates were obtained in winter for young sows that were inseminated by adult boars. In the summer, the most consolidated were young sows inseminated by young boars.

Keywords: pig breeding, sows, reproductive capacity, average weight of newly born piglets, birth-weight indicator, coefficients of phenotype consolidation, seasons, age of animals.

Domestic pig breeding is one of the leading branches of animal husbandry on which the decision of providing the population with a high-value protein product of animal origin largely depends [1-2]. The increase of production is based on the fact that in recent decades in domestic livestock, and especially in pig breeding, significant progress has been made [3-4]. Improving the efficiency of pork production is due to improvements in individual components. Such an important element as the reproductive capacity of sows is no exception [5-10].

The efforts of scientists and producers are aimed at increasing the number of 
piglets obtained from one sow during the year. In the development of modern breeding programs, significant attention is focused primarily on improving the reproductive characteristics of sows [11-12].

Current trends in climate change require more attention to the study of sow productivity under the influence of certain paratypic factors. Although there is an opinion about the absence of such influence [13]. At the same time, the reproductive capacity of sows is one of the traits with a low level of inheritance, the influence of which on paratypic factors is significant [14-16].

In recent years, there has been a significant improvement in domestic farms in terms of the main indicator that characterizes the reproductive quality of sows - fertility. Accordingly, there is a need to assess and control no less important indicator - number of high-birth-weight in pigs. There is a high and medium level of correlations between the main indicators of reproductive capacity, which increases the importance of studying the level of basic indicators, among which high-birth-weight is one of the leading [17-20].

Thus, given the relevance of this research area, the aim of this work was to study the effect sows' and boars' age on their offsprings' high-birth-weight, considering the season of the year and the age of the animals.

Materials and methods of research. The research was conducted in the experimental farm of SE "Gontarivka" of Vovchansky district of Kharkiv region, on the basis of a breeding farm for keeping Welsh pigs during 2016-2017. Natural mating of sows is used on the farm to reproduce the livestock. The research was a continuation of the work [21] started at this stage, with the study of a wider range of age combinations of boars and sows and the influence of the season of the year on the indicator of fertility and its phenotypic consolidation. The research was conducted based on traditional approaches [22].

Insemination of sows was performed according to the study scheme (Table 1).

Table 1

Scheme of study

\begin{tabular}{|c|c|c|c|c|c|}
\hline \multicolumn{2}{|c|}{$\begin{array}{c}\text { The first series } \\
\text { winter farrowing) }\end{array}$} & \multicolumn{2}{c|}{$\begin{array}{c}\text { The second series } \\
\text { (summer farrowing) }\end{array}$} & \multicolumn{2}{c|}{$\begin{array}{c}\text { Age of ani- } \\
\text { mals, months }\end{array}$} \\
\hline $\begin{array}{c}\text { Group of } \\
\text { animals }\end{array}$ & $\begin{array}{c}\text { number of sows in } \\
\text { the group, heads }\end{array}$ & $\begin{array}{c}\text { group of } \\
\text { animals }\end{array}$ & $\begin{array}{c}\text { number of sows in } \\
\text { the group, heads }\end{array}$ & sows & boars \\
\hline I & 9 & V & 7 & 48 & 48 \\
\hline II & 9 & VI & 10 & 18 & 48 \\
\hline III & 8 & VII & 9 & 24 & 24 \\
\hline IV & 9 & VIII & 9 & 18 & 18 \\
\hline
\end{tabular}

35 experimental sows and 4 Welsh boars of different ages and live weight were selected for experimental work on the breeding farm. Four groups of sows were formed. In order to study the impact of the season on the productivity of sows, the first series of studies was conducted in the fall, the second series - in the spring according to the same scheme. Used in both series of studies of the same animals (both paternal and maternal component).

: the first time in 18-20 hours after the establishment of the sexual arousal, again - in 12-18 hours. In the first period of gestation sows were kept in groups of 7-10 heads. One and a half months before farrowing sows were placed 4-5 heads in the stall, and a week before farrowing were transferred to individual stalls. During gestation the sows of the experimental groups were placed in identical conditions of feeding and keeping. 
Evaluation of the degree of phenotypic consolidation of the main features of pig productivity was performed by Yu. P. Polupan [23], to the entire estimated group of animals (for both seasons at different live weights) by the formulas (1-2):

$$
\begin{aligned}
& \mathrm{K}_{1}=1-\frac{\sigma_{\Gamma}}{\sigma_{3}} \\
& \mathrm{~K}_{2}=1-\frac{\mathrm{Cv}_{\Gamma}}{\mathrm{Cv}_{3}}
\end{aligned}
$$

where: $\mathrm{K}_{1}, \mathrm{~K}_{2}$ - the degree of phenotypic consolidation of the evaluated group;

$\sigma_{2}$ та $C v_{2}$ - standard deviation and coefficient of variability of the evaluated group of animals on a specific feature;

$\sigma_{3}$ та $C v_{3}$ - the same indicators of the general population.

Indicators obtained experimentally were processed by the method of variation statistics [24-25], using MS Excel software.

Research results and discussion. In different groups of animals, high-birthweight ranged from 1.1 to $1.21 \mathrm{~kg}$ (Fig.). The average value of this indicator for all sows for both studied seasons of the year was $1.16 \mathrm{~kg}$. High-birth-weight indicator in all sows of the period in winter farrowing was $1.74 \%$ higher compared to summer farrowing in all sows of the period, although the difference between these groups was unlikely. Among sows of different ages, which were inseminated with boars of different ages, in the winter the higher values were young sows at the age of 18 months, which were inseminated with young boars of the same age $(\mathrm{p}<0.01$ compared with young sows that were inseminated with adult boars - II group). Between sows of different ages, which were inseminated with boars of different ages, in the summer period the higher values were middle-aged (24 months), which were inseminated with middle-aged boars (24 months) ( $\mathrm{p}<0.01$ compared to young sows in winter period, which were inseminated with adult boars - group II and $\mathrm{p}<0.05$ compared to young sows in the summer period, which were inseminated with adult boars - group VI). That in the summer period for the middle-aged sows (24 months), which were inseminated with boars of the same age (group VII), were obtained maximum values of high-birth-weight, which were higher than the sows of other groups by 10.00-0.83\%.

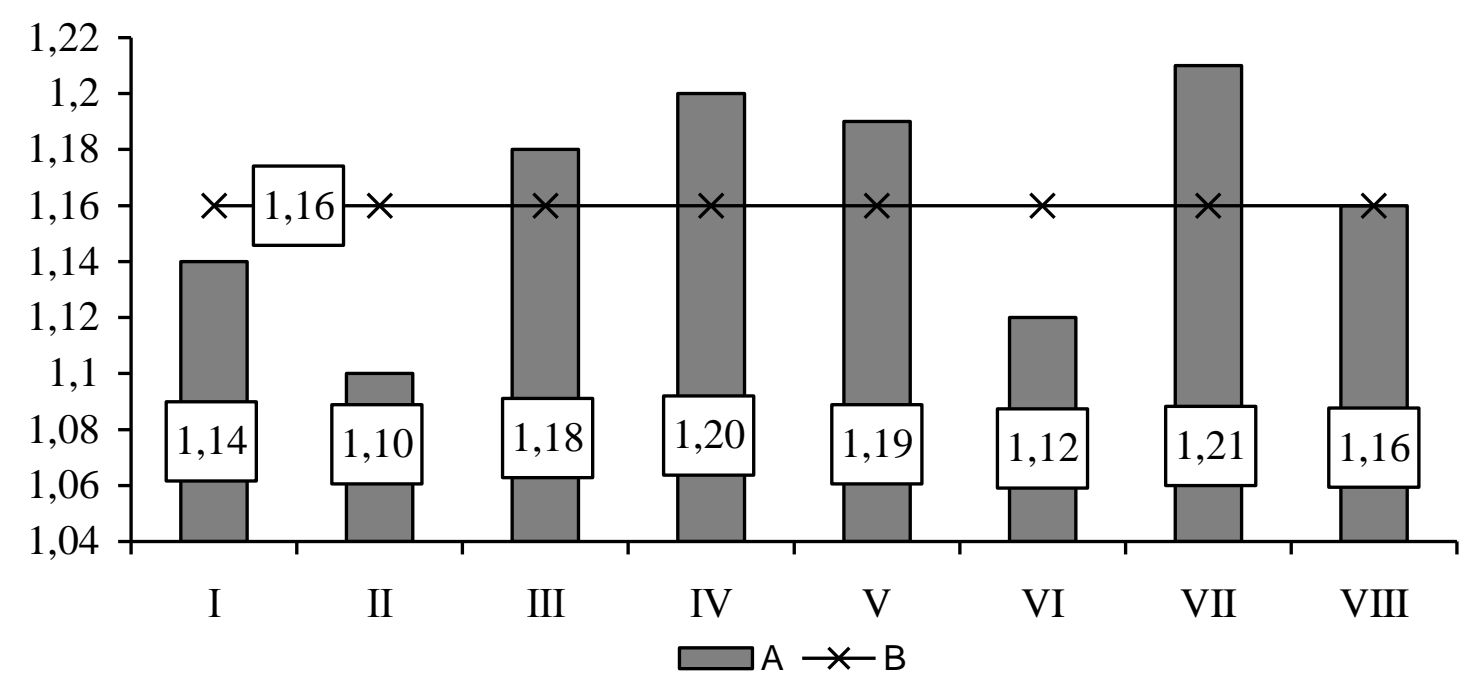

Fig. 1. Indicators of high-birth-weight of sows 
After assessing the rate of high-birth-weight, the coefficients of phenotypic consolidation were calculated (Table 2).

Table 2

Coefficients of phenotypic consolidation of sows high-birth-weight index

\begin{tabular}{|l|c|c|c|}
\hline \multirow{2}{*}{ Groups } & \multirow{2}{*}{ heads } & High-birth-weight index, kg \\
\cline { 3 - 4 } & \multicolumn{3}{|c|}{ Winter farrowing } \\
\hline \multicolumn{3}{|c|}{$\mathbf{K}_{\mathbf{2}}$} \\
\hline I & 9 & $-0,147$ & $-0,162$ \\
\hline II & 9 & $+0,350$ & $+0,314$ \\
\hline III & 8 & $+0,080$ & $+0,092$ \\
\hline IV & 9 & $+0,080$ & $+0,111$ \\
\hline \multicolumn{3}{|c|}{ Summer farrowing } \\
\hline V & 7 & $-0,170$ & $-0,145$ \\
\hline VI & 10 & $+0,178$ & $+0,148$ \\
\hline VII & 9 & $-0,017$ & $+0,026$ \\
\hline VIII & 9 & $+0,315$ & $+0,312$ \\
\hline
\end{tabular}

Of all the assessed groups of sows for both periods, the lowest values of consolidation on the basis of high-birth-weight were obtained for adult sows (48 months), which were inseminated with adult boars (48 months) in winter and summer, as well as for a group of middle-aged sows ( 24 months). which were inseminated by middle-aged boars (24 months) in the summer. Unlike sows of these three groups, the most consolidated indicators of high-birth-weight were obtained in the winter for young sows (18 months), which were inseminated with adult boars (48 months). In summer, the most consolidated were young sows (18 months), which were inseminated with young boars (18 months).

Conclusions. Probable differences in the rate of high-birth-weight between the sows of different groups at different times of the year were established. For middle-aged sows ( 24 months), which were inseminated with middle-aged boars ( 24 months), the maximum values of high-birth-weight were obtained, which were higher than the sows of other groups by 10.00-0.83\% $\%<0.01$ in compared to young sows in the winter, which were inseminated with adult boars and $\mathrm{p}<0.05$ compared to young sows in the summer, which were inseminated with adult boars).

Differences in the level of consolidation of the high-birth-weight rate at different age combinations of sows and boars were revealed. The most consolidated indicators of high-birth-weight were obtained in the winter for young sows (18 months), which were inseminated with adult boars (48 months). In summer, the most consolidated were young sows (18 months), which were inseminated with young boars (18 months). No significant differences in the consolidation of the studied feature in different periods were found.

\section{Бібліографічний список}

1. Жукорський О. М., Никифорук О. В. Галузь свинарства - реальна та прогнозована загроза для довкілля. Агроекологічний журнал. 2013. №. 3. С. 102107.

2. Schneider Uwe A., Pushpam K. Greenhouse gas emission mitigation through agriculture. Choices. 2008. V. 23. Is. 1. Retrieved from : http:// purl.umn.edu/94500 
3. Hladiy M. V., Polupan Y. P., Kovtun S. I., Kuzebnij S. V., Vyshnevskiy L. V., Kopylov K. V., Shcherbak O. V. Scientific and organizational aspects of generation, genetics, reproduction biotechnology and protection of the genofonds in livestock breeding. Animal Breeding and Genetics. 2018. № 56. P. 5-14. DOI: $10.31073 /$ abg.56.01.

4. Ващенко О. В. Комбінаційна здатність спеціалізованих порід і типів свиней в промисловому схрещуванні. Розведення і генетика тварин : міжвідом. темат. наук. зб. / Інститут розведення і гентики тварин ім. М.В. Зубця. Київ, 2017. № 53. P. 84-90. DOI: 10.31073/abg.53.11.

5. Храмкова О. М. Відтворювальні якості свиноматок за різних поєднань порід і типів. Theoretical and Applied Veterinary Medicine. 2019. №7(2). C. 115-119. DOI 10.32819/2019.71021.

6. Ц Церенюк О. М., Акімов О. В., Шкавро Н. В., Череута Ю. В. Індекси будови тіла двопородних ремонтних свинок та свиноматок. Науково-технічний бюлетень Інституту тваринництвва НААН. Харків, 2019. № 122. С. 248-257. DOI 10.32900/2312-8402-2019-122-248-257.

7. Мартинюк I. М., Церенюк О. М., Акімов О. В. Заплідненість та багатоплідність свиноматок залежно від кратності осіменіння у різні пори року. Науково-технічний бюлетень Інституту тваринництва НААН. Харків, 2019. № 121. C. 156-162. DOI 10.32900/2312-8402-2019-121-156-162.

8. Tsereniuk O., Susol R., Bordun O., Paliy A., Shkromada O., Akimov O., Tsereniuk M., Dependence of sows phenotypic consolidation of productivity on the reason of their culling due in index selection. Porc Res. 2019. № 9(1). P. 15-20.

9. Tsereniuk O., Tsereniuk M., Akimov O., Paliy A., Nanka O., Shkromada O., Pomitun I., Dependence of sows' productivity on the reason of their culling, in index selection. Porc Res. 2018. № 8(1). P. 17-23.

10. Халак В. І., Гутий Б. В., Стадницька О. І. Відгодівельні та м'ясні якості молодняку свиней різного походження та інтенсивності формування у ранньому онтогенезі. Науковий вісник Львівського національного університету ветеринарної медицини та біотехнологій ім. С. 3. Гжицького. Серія: Сільськогосподарські науки. Львів, 2019. Т. 21. № 91. С. 10-15. https://doi.org/10.32718/nvlvet-a9102

11. Hanenberg E. H. A. T., Knol E. F., Merks J. W. M. Estimates of genetic parameters for reproduction traits at different parities in Dutch Landrace pigs. Livestock Production Science. 2001. № 69(2). P. 179-186. DOI 10.1016/S0301-6226(00)00258-X

12. Крамаренко С. С., Крамаренко О. С., Луговий С. І., Лихач А. В., Лихач В. Я. Аналіз головних компонент (РСА) ознак відтворення свиноматок великої білої породи. Вісник аграрної науки Причорномор'я : міжвідом. темат. наук. зб. Миколаїв, 2019. Вип. 2. С. 75-81. DOI 10.31521/2313-092X/2019-2(102)

13. Копитець Н. Г. Сучасний стан та тенденції розвитку ринку свинини в Україні. Економіка АПК. 2018. № 11. C. 44-54. DOI https://doi.org/10.32317/22211055.201811044

14. Рукавиця А. А. Аналіз впливу використання селекційних (оціночних) індексів у якості критеріїв відбору на відтворювальні якості свиноматок української м'ясної породи. Науково-технічний бюлетень Інституту тваринництва НААН. Харків, 2016. № 115. С. 195-202.

15. Церенюк О. М., Хватов А. І., Стрижак Т. А., Коваленко В. П. Об'єктивна оцінка материнської продуктивності свиней. Таврійський науковий вісник. Херсон : Херсон. держ. аграр. ун-т, 2010. Вип. 69. С. 112-126. 
16. Коваленко Т. С., Сурженко М. В. Вивчення типів успадкування полігенних ознак продуктивності свиней. Вісник Сумського національного аграрного університету. Серія: Тваринниитво. Суми, 2013. №. 1. С. 76-78.

17. Young L. D., Pumfrey R. A., Cunningham P. J., Zimmerman D. R. Heritabilities and genetic and phenotypic correlations for prebreeding traits, reproductive traits and principal components. Journal of Animal Science. 1978. № 46(4). P. 937-949. DOI 10.2527/jas1978.464937x

18. Fahmy M. H., Bernard C. S. Interrelations between some reproductive traits in swine. Canadian Journal of Animal Science. 1972. № 52(1). P. 39-45. DOI 10.4141/cjas72-004

19. Biensen N. J., Haussmann M. F., Lay D. C., Christian L. L., Ford S. P. The relationship between placental and piglet birth weights and growth traits. Animal Scienc. 1999. № 68(4). P. 709-715. DOI 10.1017/S1357729800050736

20. Крамаренко С. С., Луговий С. І., Лихач А. В., Крамаренко О. С., Лихач В. Я., Крамаренко С. С., Крамаренко А. С. Порівняльний аналіз відтворювальних ознак та кластерний аналіз свиней різних порід. Науковий вісник Львівського національного університету ветеринарної медицини та біотехнологій ім. С. 3. Гжииького. Серія : Сільськогосподарські науки. Львів, 2018. Т. 20. № 84. C. 21-26. DOI 10.15421/nvlvet8404

21. Мартинюк I. М., Бугров О. Д. Вплив віку свиноматок і кнурів породи уельс і українська м'ясна на вихід поросят в гнізді. Свинарство : міжвідом. тем. наук зб. Інституту свинарства і АПВ НААН. Полтава, 2015. Вип. 67. С. 103-106.

22. Методологія та організація наукових досліджень у тваринництві : посіб. / за ред. I. І. Ібатулліна, О. М. Жукорського. Київ : Аграрна наука, 2017. 328 с.

23. Полупан Ю. П. Оценка степени фенотипической консолидации генеалогических групп животных. Зоотехнія. 1996. № 10. С. 13-15.

24. Плохинский Н. А. Руководство по биометрии для зоотехников. Москва : Колос, 1969. 352 с.

25. Барановский Д. И., Хохлов А. М., Гетманец О. М. Биометрия в MS Excel : учеб. пособ. Харків : ФЛП Бровин А. В., 2017. 228 с.

\section{References}

1. Zhukorskyi, O. M., \& Nykyforuk, O. V. (2013). Haluz svynarstva - realna ta prohnozovana zahroza dlia dovkillia [The pig breeding industry - a real and predicted threat to the environment]. Ahroekolohichnyy zhurnal. 3, 102-107 [in Ukrainian].

2. Schneider, Uwe A., \& Pushpam, K. (2008). Greenhouse gas emission mitigation through agriculture [online] Choices. 23 (1). Retrieved from : http:// purl.umn.edu/94500 [Accessed 01 December 2019].

3. Hladiy, M. V., Polupan, Y. P., Kovtun, S. I., Kuzebnij, S. V., Vyshnevskiy, L. V., Kopylov, K. V., Shcherbak O. V. (2018). Scientific and organizational aspects of generation, genetics, reproduction biotechnology and protection of the genofonds in livestock breeding. Animal Breeding and Genetics, 56, 5-14. DOI: 10.31073/abg.56.01.

4. Vashchenko, O. (2017). Kombinatsiina zdatnist spetsializovanykh porid i typiv svynei $\mathrm{v}$ promyslovomu skhreshchuvanni. Rozvedennia i henetyka tvaryn Kombinatsiyna zdatnist' spetsializovanykh porid i typiv svyney v promyslovomu skhreshchuvanni. Rozvedennia $i$ henetyka tvaryn - Animal Breeding and Genetics. Kyiv, 53, 84-90. DOI: 10.31073/abg.53.11 [in Ukrainian].

5. Khramkova, O. M. (2019). Vidtvoriuvalni yakosti svynomatok za riznykh poiednan porid i typiv [Reproductive qualities of sows in different combinations of 
breeds and types]. Theoretical and Applied Veterinary Medicine, 7(2), 115-119. DOI 10.32819/2019.71021, [in Ukrainian].

6. Tsereniuk, O. M., Akimov, O. V., Shkavro, N. V. \& Chereuta, YU. V. (2019). Indeksy budovy tila dvoporodnykh remontnykh svynok ta svynomatok [Body structure indices for two-offspring pigs and sows.]. Naukovo-tekhnichnyi biuleten Instytutu tvarynnytstva NAAN - The Scientific and Technical Bulletin of the Institute of Animal Science NAAS of Ukraine. Kharkiv, 122, 248-257. DOI 10.32900/2312-84022019-122-248-257 [in Ukrainian].

7. Martinyuk, I. M., Tsereniuk, O. M., \& Akimov, O. V. (2019). Indeksy budovy tila dvoporodnykh remontnykh svynok ta svynomatok [Fertilization and multiplicity of sows depending on the frequency of insemination at different times of the year]. Naukovo-tekhnichnyi biuleten Instytutu tvarynnytstva NAAN - The Scientific and Technical Bulletin of the Institute of Animal Science NAAS of Ukraine. Kharkiv, 121. 156-162. DOI 10.32900/2312-8402-2019-121-156-162 [in Ukrainian].

8. Tsereniuk, O., Susol, R., Bordun, O., Paliy, A., Shkromada, O., Akimov, O., $\&$ Tsereniuk, M. (2019). Dependence of sows` phenotypic consolidation of productivity on the reason of their culling due in index selection. Porc Res. 9(1), 15-20.

9. Tsereniuk, O., Tsereniuk, M., Akimov, O., Paliy, A., Nanka, O., Shkromada, O., \& Pomitun, I. (2018). Dependence of sows' productivity on the reason of their culling, in index selection. Porc Res. 8(1), 17-23.

10. Khalak, V., Gutyj, B., \& Stadnits'ka, O. (2019). Vidhodivelni ta m'iasni yakosti molodniaku svynei riznoho pokhodzhennia ta intensyvnosti formuvannia $u$ rannomu ontohenezi [Fattening and meat qualities of young pigs of different origin and intensity of formation in early ontogenesis]. Naukovyi visnyk Lvivskoho natsionalnoho universytetu veterynarnoi medytsyny ta biotekhnolohii im. S. Z. Gzhytskoho. Seriia: Silskohospodarski nauky - Scientific Bulletin of Lviv National University of Veterinary Medicine and Biotechnology. S. Z. Gzhytsky. Series: Agricultural Sciences, 21(91), 1015. DOI 10.32718/nvlvet-a9102 [in Ukrainian].

11. Hanenberg, E. H. A. T., Knol, E. F. \& Merks, J. W. M. (2001). Estimates of genetic parameters for reproduction traits at different parities in Dutch Landrace pigs. Livestock Production Science, 69(2), 179-186. DOI 10.1016/S0301-6226(00)00258-X

12. Kramarenko, S. S., Kramarenko, O. S., Luhovyy, S. I., Lykhach, A. V. \& Lykhach, V. YA. (2019). Analiz holovnykh komponent (PCA) oznak vidtvorennia svynomatok velykoi biloi porody [Principal Component Analysis (PCA) of sows reproduction of Large White breed]. Bulletin of Agrarian Science of the Black Sea Coast Ukrainian Black Sea region agrarian science. Mykolaiv, 2, 75-81. DOI 10.31521/2313-092X/2019-2(102) [in Ukrainian].

13. Kopytets, N. H.(2018). Suchasnyi stan ta tendentsii rozvytku rynku svynyny $\mathrm{v}$ Ukraini [The current state and tendencies of pork market development in Ukraine]. Ekonomika APK - Economics of agro-industrial complex, 11, 44-54. DOI https://doi.org/10.32317/2221-1055.201811044 [in Ukrainian].

14. Rukavytsya, A. A. (2016). Analiz vplyvu vykorystannia selektsiinykh (otsinochnykh) indeksiv u yakosti kryteriiv vidboru na vidtvoriuvalni yakosti svynomatok ukrainskoi m'iasnoi porody [Analysis of the influence of the use of breeding (evaluation) indices as selection criteria on reproductive qualities of sows of Ukrainian Meat breed]. Naukovo-tekhnichnyy byuleten 'IAS NAAS - The Scientific and Technical Bulletin of the Institute of Animal Science NAAS of Ukraine, 115, 195-202, [in Ukrainian].

15. Tsereniuk, O. M., Khvatov, A. I., Stryzhak, T. A. \& Kovalenko, V. P. (2010). Obiektyvna otsinka materynskoi produktyvnosti svynei [Objective evaluation of 
maternal pig productivity]. Tavriys `kyy naukovyy visnyk - Taurian Scientific Bulletin, 69, 112-126 [in Ukrainian].

16. Kovalenko, T. S., \& Surzhenko, M. V. (2013). Vyvchennia typiv uspadkuvannia polihennykh oznak produktyvnosti svynei [Study of types of inheritance of polygenic features of pig productivity]. Bulletin of Sumy National Agrarian University. Series: Livestock - Bulletin of Sumy National Agrarian University. Series: Livestock. Sumy, 1, 76-78 [in Ukrainian].

17. Young, L. D., Pumfrey, R. A., Cunningham, P. J., \& Zimmerman, D. R. (1978). Heritabilities and genetic and phenotypic correlations for prebreeding traits, reproductive traits and principal components. Journal of Animal Science, 46(4). pp. 937-949. DOI 10.2527/jas1978.464937x

18. Fahmy, M. H., \& Bernard, C. S. (1972). Interrelations between some reproductive traits in swine. Canadian Journal of Animal Science, 52(1), 39-45. DOI 10.4141/cjas72-004.

19. Biensen, N. J., Haussmann, M. F., Lay, D. C., Christian, L. L., \& Ford, S. P. (1999). The relationship between placental and piglet birth weights and growth traits. Animal Scienc., 68(4), 709-715. DOI 10.1017/S1357729800050736

20. Kramarenko, S. S., Luhovyi, S. I., Lykhach A. V., Kramarenko O. S., Lykhach V. Ya., Kramarenko S. S., \& Kramarenko A. S. (2018). Porivnialnyi analiz vidtvoriuvalnykh oznak ta klasternyi analiz svynei riznykh porid [Comparative analysis of reproductive traits and cluster analysis of pigs of different breeds]. Naukovyi visnyk Livivskoho natsionalnoho universytetu veterynarnoi medytsyny $i$ biotekhnolohii S. Z. Hzhytskoho - Scientific Bulletin of Lviv National University of Veterinary Medicine and Biotechnology. S. Z. Gzhytsky. Series: Agricultural Sciences. Lviv, 20 (84), 21-26. DOI 10.15421/nvlvet8404, [in Ukrainian].

21. Martyniuk, I. M., \& Buhrov, O. D. (20-15). Vplyv viku svynomatok i knuriv porody uels i ukrainska m'iasna na vykhid porosiat $v$ hnizdi [Influence of the age of sows and boars of the breed of Welsh and Ukrainian Meet on the output of piglets in the litter]. Svynarstvo - Pig breeding. Poltava : Institute of Pig Breeding and APV NAAS, 67, 103-106 [in Ukrainian].

22. Ibatullin I. I., \& Zhukorskyi, O. M. (Eds.) (2017). Metodolohiya ta orhanizatsiya naukovykh doslidzhen` u tvarynnytstvi: posib [Methodology and organization of scientific research in animal husbandry: a tool]. Kyiv : Ahrarna nauka [in Ukrainian].

23. Polupan, Yu. P. (1996). Otsenka stepeni fenotipicheskoy konsolidatsii genealogicheskikh grupp zhivotnykh [Assessment of the degree of phenotypic consolidation of genealogical groups of animals]. Zootekhniia - Zootechnics, 10, 13-15 [in Russian].

24. Plokhinskiy, N. A. (1969). Rukovodstvo po biometrii dlya zootekhnikov Biometrics Guide for Livestock Specialists. Moscow : Kolos [in Russian].

25. Baranovskyi, D. I., Khokhlov, A. M., \& Getmanets, O. M. (2017). Biometriya v MS Excel [Biometry in MS Excel]. Kharkív : FLP Brovin A. V. [in Russian].

КОЭФФИЦИЕНТЫ ФЕНОТИПОВОЙ КОНСОЛИДАЦИИ ПОКАЗАТЕЛЯ КРУПНОПЛОДНОСТИ СВИНОМАТОК УЭЛЬСЬКОЙ ПОРОДЫ

Церенюк А. Н., Мартынюк И. Н., Акимов А. В., Шкавро Н. Н., Институт животноводства НААН

Бабич М., Люблинський Природоведческий университет, Польша

Целью исследований, результаты которых изложены в статье было изучение влияния возраста свиноматок и хряков на крупноплодие с учетом сезона 
года и возраста животных. Исследования проводили в опытном хозяйстве ГП ОХ «Гонтаровка» Волчанского района Харьковской области. Для воспроизводства поголовья в хозяйстве использовали естественное осеменение свиноматок. Осеменения проводили согласно схемы опыта. Для проведения экспериментальной работы на свиноферме племзавода было отобрано 35 голов основных свиноматок и 4 хряка породы уэльс разного возраста и разной живой массы. Было сформировано четыре группь маток. С челью изучения влияния сезона года на продуктивность свиноматок первую серию исследований проводили осенью, вторую - весной по той же схеме.

По разным группам животных крупноплодие колебалось в пределах от 1,1 до 1,21 кг. Среднее значение этого показателя по всем маткам по обоим изученным сезонам года составляло 1,16 кг. Крупноплодие (по всем маткам перода) в зимние опоросы было на 1,74 \% большим по сравнению с летними опоросами (по всем маткам периода), хотя и разница между этими группами была не достоверной.

Между матками разного возраста, которые были осеменены хряками разного возраста, в зимний период большие значения имели молодые матки, которые были осеменены молодыми хряками ( $<<0,01$ по сравнению с молодыми матками, которые были осеменены полновозрастными хряками). Между матками разного возраста, которые были осеменены хряками разного возраста в летний период, большие значения были у маток среднего возраста, которые были осеменены хряками среднего возраста ( $p<0,01$ по сравнению с молодыми матками в зимний период, которые были осеменены полновозрастными хряками и $p<0,05$ по сравнению с молодыми матками в летний период, которые были осеменены полновозрастными хряками). Именно в летний период по маткам среднего возраста, которые были осеменень хряками среднего возраста были получены максимальные значения крупноплодия, которые были большими за показатели маток других групп на 10,00-0,83\%.

Наиболее консолидированные показатели крупноплодия были получены в зимний период по молодым маткам, которые были осеменены полновозрастными хряками. В летний период наиболее консолидированными были молодые матки, которые были осеменены молодыми хряками.

Ключевые слова: свиноводство, свиноматки, воспроизводительная способность, крупноплодие, коэффициенты фенотипической консолидации, сезонь года, возраст животных.

\section{КОЕФІЦІСНТИ ФЕНОТИПОВОЇ КОНСОЛІДАЦІЇ ПОКАЗНИКУ ВЕЛИКОПЛІДНОСТІ СВИНОМАТОК УЕЛЬСЬКОЇ ПОРОДИ \\ Церенюк О. М., Мартинюк І. М., Акімов О. В., Шкавро Н. М., Інститут} тваринництва НААН

Бабіч М., Люблінський Природничий університет, Польща

Метою досліджень, результати якої викладені у статті, було вивчення впливу віку свиноматок $i$ кнурів на їх великоплідність із урахуванням сезону року та віку тварин. Дослідження проводилися в дослідному господарстві ДП ДГ „Гонтарівка” Вовчанського району Харківської області. Для відтворення поголів'я у господарстві використовують природне парування свиноматок. Осіменіння свиноматок було проведено згідно зі схемою досліджень. Для проведення експериментальної роботи на свинофермі племзаводу було відібрано 35 голів основних свиноматок та 4 кнури породи уельс різного віку та різної живої ваги. Було сформовано чотири групи маток. 3 метою вивчення впливу сезону року на про- 
дуктивність свиноматок, першу серію досліджень провели восени, другій серію навесні за тією ж схемою.

По різних групах тварин великоплідність коливалась в межах від 1,1 до 1,21 кг. Середнє значення иього показника по всіх матках за обох вивчених сезонів року становило 1,16 кг. Великоплідність (по усім маткам періоду) у зимові опороси була на 1,74\% вищою у порівнянні з літніми опоросами (по усім маткам періоду), хоча й різниия між иими групами була не вірогідною. Між матками різного віку, щуо були осімінені кнурами різного віку, в зимовий період вищі значення мали молоді матки, що були осімінені молодими кнурами ( $<<0,01$ у порівнянні до молодих маток, щзо були осімінені повновіковими кнурами). Між матками різного віку, щу були осімінені кнурами різного віку, в літній період вищі значення мали середнього віку, щзо були осімінені кнурами середнього віку $(p<0,01$ у порівнянні до молодих маток у зимовий період, щзо були осімінені повновіковими кнурами та $p<0,05$ у порівнянні до молодих маток у літній період, щуо були осімінені повновіковими кнурами). Саме в літній період по матках середнього віку, щзо були осімінені кнурами середнього віку були отримані максимальні значення великоплідності, щуо були вищими за показники маток інших груп на 10,00-0,83 \%.

Найбільш консолідовані показники великоплідності були отримані в зимовий період по молодих матках, щзо були осімінені повновіковими кнурами. В літній період найбільш консолідованими були молоді матки, щяо були осімінені молодими кнурами.

Ключові слова: свинарство, свиноматки, відтворна здатність, великоплідність, коефіцієнти фенотипової консолідащії, сезони року, вік тварин.

DOI 10.32900/2312-8402-2020-123-58-67

УДК 636.1.082.26:575

\title{
АСОЦАЦАТИВНІ ЗВ'ЯЗКИ ГЕНОТИПІВ КАППА-КАЗЕИНУ, БЕТА-ЛАКТОГЛОБУЛІНУ, ЛЕПТИНУ ТА СОМАТОТРОПІНУ 3 МОЛОЧНОЮ ПРОДУКТИВНІСТЮ ХУДОБИ В ПОПУЛЯЦІї СИМЕНТАЛЬСЬКОЇ ПОРОДИ
}

\author{
Бойко О. А., К. с.-Г. Н., с. н. с., \\ Poccoxa B. I., К. с-Г. Н., с. н. с., \\ Дробязко О. В., Н. с. \\ Олійниченко Є. К., К. с.-Г. н. \\ Задерихіна О. А., с. н. с. \\ Інститут тваринництва НААН
}

3 метою визначення прояву продуктивності популячії симентальської худоби проведено генотипування племінних тварин за генами, що асоційовані $з$ господарсько корисними ознаками та запропоновано застосовування результатів при плануванні перспективних планів селекційно - племінної роботи з урахуванням генотипів бугаїв-плідників.

Проведено аналіз поліморфізму генів капа-казеїну $(\kappa-C n)$, беталактоглобуліну ( $\beta L G)$, лептину (LEP) та гену соматотропіну $(G H)$ в популячії великої рогатої худоби симентальської породи (ПрАТ «Племінний завод «Червоний Велетень» Харківської області) за використання метода ПЛР-ПДРФ. Встановлено рівень продуктивності за надоєм, вмістом жиру та білку в молочі. Визначе- 